\title{
Studi Perbandingan Analisis Struktur Rumah 2 Lantai Menggunakan Kayu Glulam dan Kayu Solid Terhadap Beban Gempa
}

\author{
RAMDHAN TAUFIK, ERMA DESMALIANA, AMATULHAY PRIBADI
}

Jurusan Teknik Sipil, Institut Teknologi Nasional, Bandung

Email:rmdhntaufik@gmail.com

\begin{abstract}
ABSTRAK
Kondisi geografis Indonesia memiliki struktur tektonik kompleks. Kondisi ini membuat perencanaan rumah tinggal 2 (dua) lantai membutuhkan pertimbangan khusus dari segi kekuatan dan kekakuan. Penggunaan material kayu sebagai bahan konstruksi di Indonesia masih jarang digunakan. Kayu glulam adalah suatu produk kayu rekayasa yang dibuat dari beberapa bilah kayu yang direkatkan dengan arah sejajar serat menggunakan perekat berupa lem. Penelitian ini bertujuan untuk mengidentifikasi respon struktur pada rumah tinggal menggunakan material kayu glulam dan solid dengan bantuan program ETABS 2016. Berdasarkan analisis yang telah dilakukan, diperoleh nilai periode struktur, gaya geser dasar, dan simpangan antar lantai antara seluruh model menunjukan hasil yang berbeda, perbedaan diakibatkan dari hasil konversi berat jenis dan modulus of elastisity berdasarkan BS EN 1194:1999. Berdasarkan analisis non-linier pushover didapatkan bahwa kayu glulam Nyatoh (kayu kelas III) berada pada level pada kinerja B to IO (Immediate Occupancy), dimana hasil tersebut tidak berbeda jauh dengan kayu solid Bangkirai (kayu kelas I).
\end{abstract}

Kata Kunci: rumah tinggal, kayu glulam, non-linier pushover

\begin{abstract}
Geographical condition of Indonesia has a complex tectonic structure. These conditions create 2-storyhome-planning that require special consideration in terms of strength and rigidity. The use of wood as a construction material in Indonesia is still rarely used. Glulam wood is a wood products engineering made from wooden slats several glued with the direction of the parallel fibers using adhesives. This research aims to identify the structure of the response at home using basic material glulam and solid wood with the help of ETABS 2016 programs. Based on the analysis that has been done, obtained the value of the structure periode, base shear force, and interstory drift between all models show different results, the difference is due to the results of specific gravity conversion and modulus of elasticity base on BS EN 1194:1999. Based on non-linear pushover analysis, it shows that Nyatoh glulam wood (class III wood) was at the level of the B to IO (Immediate Occupancy) performance, where the results were not much different from Bangkirai solid wood (class I wood).
\end{abstract}

Keywords: home livingstructure, glulam wood, non-linear pushover 


\section{PENDAhUlUAN}

Indonesia merupakan salah satu negara yang memiliki sumber kekayaan alam yang melimpah, salah satunya adalah hutan. Melimpahnya hutan ini salah satunya bisa dimanfaatkan sebagai bahan konstruksi bangunan. Namun di Indonesia penggunaan kayu sedikit jarang dimanfaatkan sebagai struktur bangunan, salah satu penyebabnya adalah karena kayu di pasaran dimensi ukurannya terbatas.

Dewasa ini teknologi telah berkembang dengan pesat salah satunya di bidang material konstruksi. Kayu glulam merupakan salah satu penemuan besar di bidang material kayu. Adapun yang dimaksud dengan kayu glulam adalah beberapa lapis kayu yang direkatkan/dilaminasi untuk mendapatkan dimensi ukuran yang sesuai dengan kebutuhan. Dalam mendesain rumah tinggal 2 lantai dengan menggunakan bahan kayu glulam memiliki sedikit perbedaan dengan desain struktur yang menggunakan beton dan baja. Perbedaan tersebut terletak pada faktor koreksi dan faktor konversi dari kayu solid ke glulam. Berdasarkan latar belakang tersebut, perlu adanya penelitian mengenai kayu glulam sebagai bahan struktural untuk bangunan rumah tinggal.

\section{TINJAUAN PUSTAKA}

\subsection{Pendahuluan}

Semakin berkembangnya ilmu rekayasa material, tidak terkecuali pada rekayasa material kayu menghasilkan banyak penelitian serta penemuan dalam upaya meningkatkan ketahanan dan kekuatan material kayu sebagai bahan konstruksi. Rekayasa material kayu yang dilakukan untuk meningkatkan ketahanan dan kekuatan material kayu salah satunya dengan melakukan teknik laminasi beberapa jenis kayu yang dibuat per layer menjadi satu elemen struktur, yang dapat digunakan sebagai balok atau kolom pada satu rangkaian system struktur bangunan kayu.

\subsection{Sifat-Sifat Kayu}

Kayu memiliki beberapa sifat yang tidak dapat ditiru oleh bahan-bahan lain. Diantaranya yang termasuk sifat fisik kayu yaitu berat dan berat jenis, keawetan, warna, tekstur, arah serat, kesan raba, bau dan rasa, nilai dekoratif, dan higroskopis. Untuk sifat mekanik yaitu keteguhan tarik, keteguhan tekan, keteguhan geser, keteguhan lengkung, kekakuan, keuletan, kekerasan, dan keteguhan belah.

\subsection{Macam Penggunaan Kayu}

Penggunaan kayu dalam dunia konstruksi diantaranya adalah kayu sebagai bahan bangunan, kayu sebagai salah satu komponen jembatan, kayu sebagai dinding, kayu sebagai lantai, dan kayu sebagai kuda-kuda.

\subsection{Jenis Kayu Olahan}

Jenis kayu olahan ini sangat beragam sehingga dapat menyesuaikan dengan kebutuhan. Disebut kayu olahan karena berasal dari olahan kayu asli yang dicampur dengan zat kimia. Diantaranya adalah plywood, blackboard, medium density fiberboard, dan particle board.

\subsection{Kayu Glulam}

Kayu glulam adalah suatu produk yang dibuat dari beberapa bilah kayu yang direkat dengan arah serat sejajar. Perekatan dilakukan kearah lebar (horizontal) dan kearah tebal (vertikal). Hasil perkatan tersebut dapat berupa papan atau balok tergantung dari ukuran tebal dan lebarnya (Sulastiningsih, I.M., 2005). 


\subsection{Perilaku Mekanik Kayu Glulam}

Didalam perencanaan kayu glulam, kekuatan mekanik kayu glulam dapat ditentukan berdasarkan kekuatan kayu aslinya dengan mengikuti persamaan Eurocode 5 Design of Timber Structure, seperti pada Tabel 1.

Tabel 1. Konversi Sifat Mekanik Kayu Glulam

\begin{tabular}{cc}
\hline Properti & $\begin{array}{c}\text { Persamaan berdasarkan } \\
\text { BS EN1194:1999 }\end{array}$ \\
\hline Kuat lentur [MPa] & $F_{m, g, k}=7+1,15 \mathrm{ft}$ \\
\hline Kuat tarik sejajar serat [MPa] & $F_{t, 0, g, k}=5+0,8 \mathrm{ft}$ \\
\hline Kuat tekan sejajar serat [MPa] & $F_{c, 0, g, k}=7,2 f_{t}^{0,45}$ \\
\hline Kuat geser [MPa] & $F_{V, g, k}=0,32 f_{t}^{0,8}$ \\
\hline Modulus elasitisitas [MPa] & $E_{g}=1,05 E$ \\
\hline Modulus geser [MPa] & $F_{g, \text { mean }}=0,065 E$ \\
\hline Kerapatan [MPa] & $\rho_{g}=\rho_{i, k}$ \\
\hline
\end{tabular}

\subsection{Pembebanan}

Pembebanan dalam penelitian ini menggunakan peraturan SNI 1727-2013 dengan beban yang bekerja pada struktur adalah beban mati (DL), beban hidup (LL), beban mati tambahan $(\mathrm{SiDL})$, beban gempa (EQx dan $\left.\mathrm{EQ}_{\mathrm{y}}\right)$, dan beban atap (R).

\subsection{Kombinasi Pembebanan}

Kombinasi pembebanan dalam penelitian ini mengacu pada SNI 1726-2012 tentang Tata Cara Perencanaan Ketahanan Gempa untuk Struktur Bangunan Gedung dan Non Gedung. Kombinasi pembebanan dapat dilihat pada Tabel 2.

Tabel 2. Kombinasi Pembebanan

\begin{tabular}{|c|c|}
\hline No & Kombinasi Pembebanan \\
\hline 1 & $1,4 \mathrm{DL}+1,4 \mathrm{SiDL}$ \\
\hline 2 & $1,2 \mathrm{DL}+1,2 \mathrm{SiDL}+1,6 \mathrm{LL}+0.5 \mathrm{R}$ \\
\hline 3 & $1,2 \mathrm{DL}+1,2 \mathrm{SiDL}+1 \mathrm{LL}+1,6 \mathrm{R}$ \\
\hline 4 & $\left(1,2+1,2 \mathrm{~S}_{\mathrm{DS}}\right) \mathrm{DL}+\left(1,2+1,2 \mathrm{~S}_{\mathrm{DS}}\right) \mathrm{SiDL}+1 \mathrm{LL}+(0,3 \rho) \mathrm{Eq}_{\mathrm{x}}+(1 \rho) \mathrm{Eq}_{\mathrm{y}}$ \\
\hline 5 & $\left(1,2+1,2 \mathrm{~S}_{\mathrm{DS}}\right) \mathrm{DL}+\left(1,2+1,2 \mathrm{~S}_{\mathrm{DS}}\right) \mathrm{SiDL}+1 \mathrm{LL}+(0,3 \rho) \mathrm{Eq}_{x}-(1 \rho) \mathrm{Eq}_{y}$ \\
\hline 6 & $\left(1,2+1,2 S_{D S}\right) \mathrm{DL}+\left(1,2+1,2 S_{D S}\right) S i D L+1 L L-(0,3 \rho) \mathrm{Eq}_{x}+(1 \rho) \mathrm{Eq}_{y}$ \\
\hline 7 & $\left(1,2+1,2 S_{D S}\right) D L+\left(1,2+1,2 S_{D S}\right) S i D L+1 L L-(0,3 \rho) E_{x}-(1 \rho) E q_{y}$ \\
\hline 8 & $\left(1,2+1,2 \mathrm{~S}_{\mathrm{DS}}\right) \mathrm{DL}+\left(1,2+1,2 \mathrm{~S}_{\mathrm{DS}}\right) \mathrm{SiDL}+1 \mathrm{LL}+(1 \rho) \mathrm{Eq}_{\mathrm{x}}+(0,3 \rho) \mathrm{Eq}_{\mathrm{y}}$ \\
\hline 9 & $\left(1,2+1,2 S_{D S}\right) \mathrm{DL}+\left(1,2+1,2 \mathrm{~S}_{\mathrm{DS}}\right) \mathrm{SiDL}+1 \mathrm{LL}+(1 \rho) \mathrm{Eq}_{\mathrm{x}}-(0,3 \rho) \mathrm{Eq}_{\mathrm{y}}$ \\
\hline 10 & $\left(1,2+1,2 S_{D S}\right) \mathrm{DL}+\left(1,2+1,2 \mathrm{~S}_{\mathrm{DS}}\right) \mathrm{SiDL}+1 \mathrm{LL}-(1 \rho) \mathrm{Eq}_{x}+(0,3 \rho) \mathrm{Eq}_{\mathrm{y}}$ \\
\hline 11 & $\left(1,2+1,2 S_{D S}\right) \mathrm{DL}+\left(1,2+1,2 \mathrm{~S}_{\mathrm{DS}}\right) \mathrm{SiDL}+1 \mathrm{LL}-(1 \rho) \mathrm{Eq}_{\mathrm{x}}-(0,3 \rho) \mathrm{Eq}_{\mathrm{y}}$ \\
\hline 12 & $\left(1,2+1,2 \mathrm{~S}_{\mathrm{DS}}\right) \mathrm{DL}+\left(1,2+1,2 \mathrm{~S}_{\mathrm{DS}}\right) \mathrm{SiDL}+(0,3 p) \mathrm{Eq}_{\mathrm{x}}+(1 \rho) \mathrm{Eq}_{\mathrm{y}}$ \\
\hline 13 & $\left(1,2+1,2 S_{D S}\right) \mathrm{DL}+\left(1,2+1,2 \mathrm{~S}_{\mathrm{DS}}\right) \mathrm{SiDL}+(0,3 \rho) \mathrm{Eq}_{\mathrm{x}}-(1 \rho) \mathrm{Eq}_{\mathrm{y}}$ \\
\hline 14 & $\left(1,2+1,2 S_{D S}\right) D L+\left(1,2+1,2 S_{D S}\right) \operatorname{SiDL}-(0,3 \rho) \mathrm{Eq}_{x}+(1 \rho) \mathrm{Eq}_{y}$ \\
\hline 15 & $\left(1,2+1,2 S_{D S}\right) D L+\left(1,2+1,2 S_{D S}\right) \operatorname{SiDL}-(0,3 p) \mathrm{Eq}_{x}-(1 \rho) \mathrm{Eq}_{\mathrm{y}}$ \\
\hline 16 & $\left(1,2+1,2 \mathrm{~S}_{\mathrm{DS}}\right) \mathrm{DL}+\left(1,2+1,2 \mathrm{~S}_{\mathrm{DS}}\right) \mathrm{SiDL}+(1 \rho) \mathrm{Eq}_{\mathrm{x}}+(0,3 p) \mathrm{Eq}_{\mathrm{y}}$ \\
\hline 17 & $\left(1,2+1,2 \mathrm{~S}_{\mathrm{DS}}\right) \mathrm{DL}+\left(1,2+1,2 \mathrm{~S}_{\mathrm{DS}}\right) \mathrm{SiDL}+(1 \rho) \mathrm{Eq}_{\mathrm{x}}-(0,3 \rho) \mathrm{Eq}_{\mathrm{y}}$ \\
\hline 18 & $\left(1,2+1,2 S_{D S}\right) D L+\left(1,2+1,2 S_{D S}\right) S i D L-(1 \rho) E_{x}+(0,3 p) \mathrm{Eq}_{y}$ \\
\hline 19 & $\left(1,2+1,2 S_{D S}\right) \mathrm{DL}+\left(1,2+1,2 \mathrm{~S}_{\mathrm{DS}}\right) \mathrm{SiDL}-(1 \rho) \mathrm{Eq}_{\mathrm{x}}-(0,3 \rho) \mathrm{Eq}_{\mathrm{y}}$ \\
\hline 20 & ENVELOPE \\
\hline
\end{tabular}




\subsection{Faktor Keutamaan dan Kategori Risiko Bangunan}

Berdasarkan SNI 1726-2012, jenis pemanfaatan bangunan gedung untuk fungsi rumah tinggal mempunyai kategori risiko II dengan faktor keutamaan gempa $\left(I_{e}\right)$ adalah 1 .

\subsection{Pemilihan Sistem Struktur}

Penelitian ini menggunakan dinding rangka ringan (kayu) yang dilapisi dengan panel struktur kayu dengan koefisien modifikasi respon $(R)$ adalah 7.

\subsection{Data Gempa}

Parameter gempa untuk kategori gempa tinggi dapat diketahui melalui website online (Pusat Penelitian dan Pengembangan Perumahan dan Permukiman (Pusat Litbang Perumahan dan Permukiman), diperoleh data gempa yang dapat dilihat pada Tabel 3. Gambar 1merupakan respon spectrum untuk tanah sedang di Kota Bandung.

\section{Tabel 3. Data Kegempaan}

\begin{tabular}{lc}
\hline Variabel & Nilai \\
\hline$P G A[\mathrm{~g}]$ & 0,57 \\
\hline$S_{S}[\mathrm{~g}]$ & 1,45 \\
\hline$S_{1}[\mathrm{~g}]$ & 0,48 \\
\hline$C_{R S}$ & 0,97 \\
\hline$C_{R 1}$ & 0,90 \\
\hline$F_{P G A}$ & 1,00 \\
\hline$F_{A}$ & 1,00 \\
\hline$F_{V}$ & 1,51 \\
\hline$P S A[\mathrm{~g}]$ & 0,57 \\
\hline$S_{M S}[\mathrm{~g}]$ & 1,45 \\
\hline$S_{M 1}[\mathrm{~g}]$ & 0,73 \\
\hline$S_{D S}[\mathrm{~g}]$ & 0,96 \\
\hline$S_{D 1}[\mathrm{~g}]$ & 0,49 \\
\hline$T_{0}[$ detik $]$ & 0,10 \\
\hline$T_{S}[$ detik $]$ & 0,50 \\
\hline
\end{tabular}

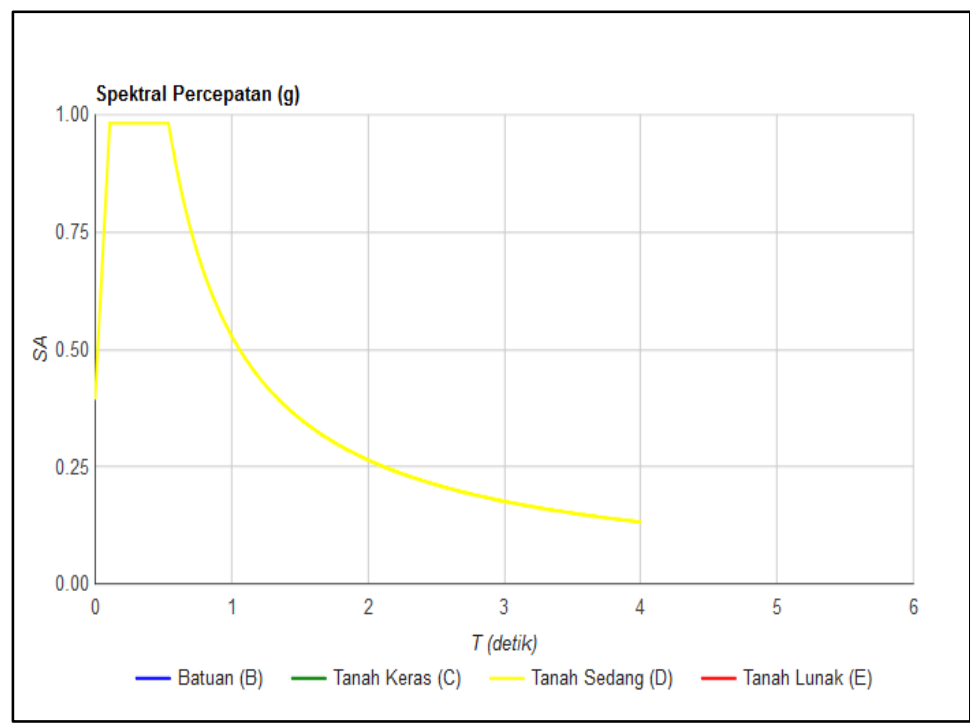

Gambar 1.Respon spektrum untuk tanah sedang (Sumber: http://puskim.pu.go.id/Aplikasi/desain_spektra_indonesia_2011/) 


\subsection{Periode Fundamental Pendekatan}

Berdasarkan SNI 1726-2012, nilai periode pendekatan batas bawah untuk tipe struktur semua sistem struktur lainnya dengan nilai $C_{t}$ adalah 0,0488 dan nilai $x$ adalah 0,77 . Persamaan batas bawah dapat dilihat pada Persamaan 1.

$$
T_{\text {a minimum }}=C_{t} * h_{n}^{x}
$$

dengan:

$T_{a \min }=$ periode minimum [detik],

$C_{t} \quad=$ tipe struktur,

$h_{n} \quad=$ ketinggian struktur bangunan [m].

Periode fundamental pendekatan batas atas ditentukan dengan Persamaan 2.

$$
T_{a \text { maximum }}=C_{u} * T_{\text {a minimum }}
$$

dengan:

$C_{u} \quad=$ parameter percepatan respon spektrum desain pada 1 detik.

\subsection{Gaya Geser Seismik}

Berdasarkan SNI 1726:2012 persamaan gaya geser seimik dapat dilihat pada Persamaan 3.

$$
V=C_{s} * W
$$

dengan:

$V \quad=$ gaya geser dasar [kN],

$C_{S} \quad=$ koefisien respon seismik,

$W \quad=$ berat seismik efektif [kN].

\subsection{Simpangan Antar Tingkat}

Nilai simpangan antar tingkat izin harus lebih besar dari selisih defleksi terbesar antar tingkat. Persamaan defleksi pusat massa dapat dilihat pada Persamaan 4.

$$
\delta_{x}=\frac{C_{d} * \delta_{x e}}{I_{e}}
$$

dengan:

$\delta_{x}=$ simpangan antar lantai [mm],

$C_{d} \quad=$ faktor pembesaran defleksi,

$\delta_{x e} \quad=$ defleksi maksimum pada lokasi lantai yang ditinjau [mm],

$I_{e} \quad=$ faktor keutamaan struktur.

Persamaan simpangan antar tingkat izin didasarkan pada kategori risiko dan ketinggian setiap tingkat $\left(h_{s x}\right)$ dengan kategori risiko II, dapat dilihat pada Persamaan 5.

$$
\Delta_{a}=0,02 h_{s x}
$$

dengan:

$\Delta_{a} \quad=$ simpangan izin [mm],

$h_{s x} \quad=$ ketinggian setiap lantai [mm]. 


\section{METODE PENELITIAN}

Bagan alir dari penelitian ini dapat dilihat pada Gambar 2.

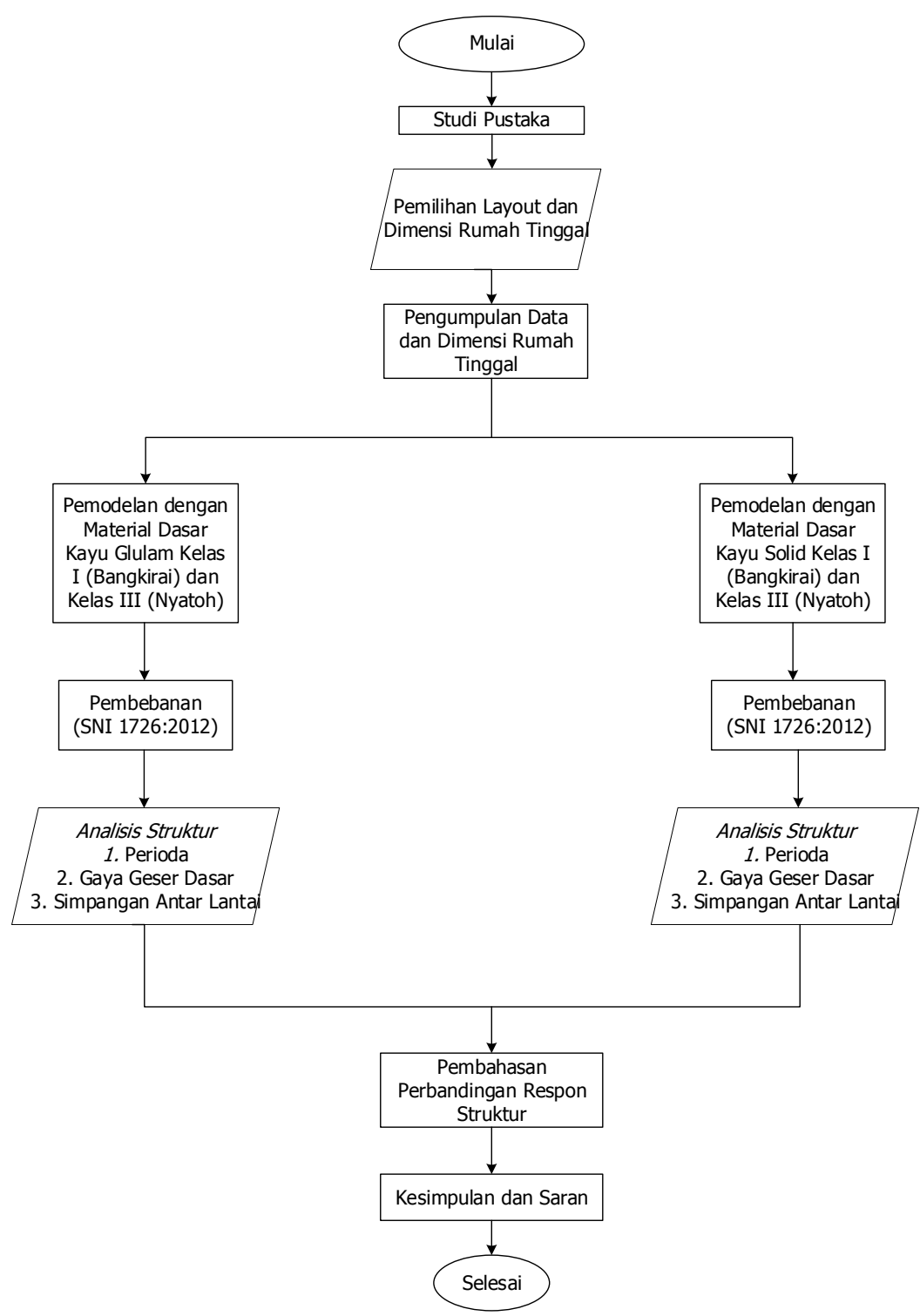

Gambar 2. Bagan alir penelitian

\section{DESAIN DAN PEMODELAN}

Dalam penelitian ini, pemodelan dengan 4 kasus struktur rumah tinggal yaitu struktur kayu solid dan glulam dengan jenis kayu yang berbeda yaitu kayu Bangkirai dengan kayu Nyatoh dengan kategori desain seismik D. Sistem rangka yang digunakan adalah dinding ringan (kayu) yang dilapisi dengan panel struktur kayu yang dimaksudkan untuk tahanan geser dengan data bangunan sebagai berikut:

1. Jumlah lantai rumah tinggal untuk keempat kasus adalah 2 lantai dengan ketinggian pada lantai 1 adalah 3,6 meter dan lantai 2 adalah 3 meter.

2. Berat Jenis $(\rho)$ kayu solid Bangkirai sebesar $9,1 \mathrm{kN} / \mathrm{m}^{3}$.

3. Modulus of elastisity $(E)$ kayu solid Bangkirai sebesar $23.330,59 \mathrm{MPa}$.

4. Berat Jenis $(\rho)$ kayu solid Nyatoh sebesar $6,7 \mathrm{kN} / \mathrm{m}^{3}$.

5. Modulus of Elastisity $(E)$ kayu solid Nyatoh sebesar $8.687,07 \mathrm{MPa}$. 
Model dan denah pembalokan struktur yang digunakan dalam penelitian ini dapat dilihat pada Gambar 3 dan Gambar 4.

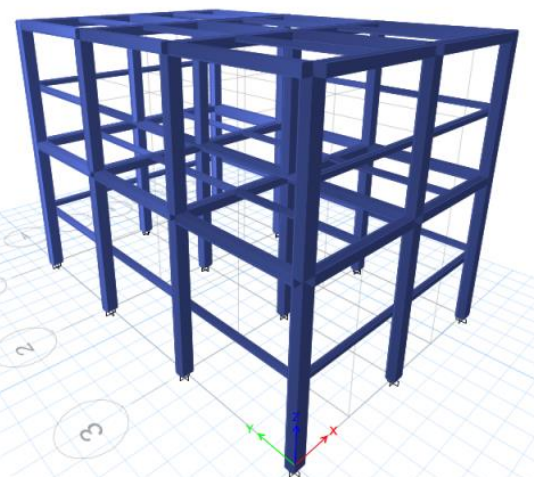

Gambar 3. Pemodelan struktur 3D

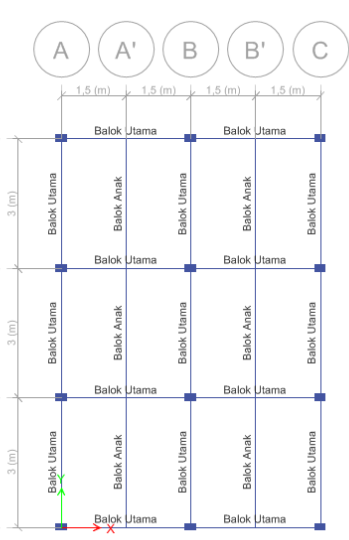

Gambar 4. Denah pembalokan struktur

Hasil analisis pada struktur beton cast in situ dan beton pracetak didapatkan data yang dapat dilihat pada Tabel 4.

Tabel 4. Dimensi Balok dan Kolom

\begin{tabular}{|c|c|c|c|c|c|c|}
\hline \multirow[b]{2}{*}{ Glulam } & \multicolumn{3}{|c|}{ Balok } & \multicolumn{3}{|c|}{ Kolom } \\
\hline & Nama & $b[\mathbf{m m}]$ & $\begin{array}{c}h \\
{[\mathrm{~mm}]}\end{array}$ & Nama & $\begin{array}{c}b \\
{[\mathrm{~mm}]}\end{array}$ & $\begin{array}{c}h \\
{[\mathrm{~mm}]}\end{array}$ \\
\hline \multirow{2}{*}{ Glulam Bangkirai } & B-I & 180 & 180 & & \multirow{4}{*}{270} & \multirow{4}{*}{180} \\
\hline & B-A & 90 & 90 & $G-B$ & & \\
\hline \multirow{2}{*}{ Glulam Nyatoh } & B-I & 180 & 180 & \multirow{2}{*}{ G-Ny } & & \\
\hline & B-A & 90 & 90 & & & \\
\hline \multirow[b]{2}{*}{ Solid } & \multicolumn{3}{|c|}{ Balok } & \multicolumn{3}{|c|}{ Kolom } \\
\hline & Nama & $b[\mathrm{~mm}]$ & $\begin{array}{c}h \\
{[\mathrm{~mm}]}\end{array}$ & Nama & $\begin{array}{c}b \\
{[\mathrm{~mm}]}\end{array}$ & $\begin{array}{c}h \\
{[\mathrm{~mm}]}\end{array}$ \\
\hline \multirow{2}{*}{ Solid Bangkirai } & B-I & 180 & 180 & \multirow{2}{*}{ S-B } & \multirow{4}{*}{270} & \multirow{4}{*}{180} \\
\hline & B-A & 90 & 90 & & & \\
\hline \multirow{2}{*}{ Solid Nyatoh } & B-I & 180 & 180 & \multirow{2}{*}{ S-Ny } & & \\
\hline & B-A & 90 & 90 & & & \\
\hline
\end{tabular}

Dari hasil analisis diperoleh periode struktur yang menunjukkan bahwa struktur kayu glulam tidak jauh berbeda dengan kayu solid, dikarenakan berat jenis dari kedua jenis kayu berbeda 1,05 yang mana nilai 1,05 ini didapat dari hasil konversi rumus Eurocode 5.Sedangkan periode kayu Bangkirai dan kayu Nyatoh didapatkan hasil yang berbeda 1,5 kali lebih kecil. Periode yang diperoleh dari pemodelan dapat dilihat pada Tabel $\mathbf{5}$.

Tabel 5. Periode Struktur Kayu Solid dan Glulam

\begin{tabular}{ccccc}
\hline \multirow{2}{*}{ Mode } & \multicolumn{2}{c}{ Bangkirai } & \multicolumn{2}{c}{ Nyatoh } \\
\cline { 2 - 5 } & Solid & Glulam & Solid & Glulam \\
\cline { 2 - 5 } & $\begin{array}{c}\boldsymbol{T} \\
\text { [detik] }\end{array}$ & $\begin{array}{c}\boldsymbol{T} \\
\text { [detik] }\end{array}$ & $\begin{array}{c}\boldsymbol{T} \\
\text { [detik] }\end{array}$ & $\begin{array}{c}\boldsymbol{T} \\
\text { [detik] }\end{array}$ \\
\hline 1 & 0,31 & 0,31 & 0,50 & 0,49 \\
\hline 2 & 0,26 & 0,26 & 0,41 & 0,40 \\
\hline 3 & 0,24 & 0,24 & 0,38 & 0,38 \\
\hline
\end{tabular}


Tabel 6. Gaya Geser Dasar Kayu Solid dan Glulam

\begin{tabular}{|c|c|c|c|c|}
\hline \multirow{3}{*}{ Jenis Kayu } & \multicolumn{4}{|c|}{$\begin{array}{l}\text { Gaya Geser Dasar dalam Arah Sumbu X dan Arah Sumbu Y } \\
\qquad V[k N]\end{array}$} \\
\hline & \multicolumn{2}{|c|}{ Solid } & \multicolumn{2}{|c|}{ Glulam } \\
\hline & $F \boldsymbol{X}$ & $F \boldsymbol{Y}$ & $F X$ & $F Y$ \\
\hline Bangkirai & 23,01 & 23,40 & 23,57 & 24,01 \\
\hline Nyatoh & 21,46 & 21,72 & 21,87 & 22,17 \\
\hline
\end{tabular}

Hasil analisis perbandingan nilai gaya geser dasar (base shear) dalam menggunakan kayu rekayasa glulam didapatkan nilai rata-rata sebesar 34,447 kN untuk arah $X$ dan 33,4339 kN untuk arah $\mathrm{Y}$, sedangkan gaya geser dalam menggunakan kayu solid didapatkan hasil sebesar 33,1214 kN untuk arah X dan 32,084 untuk arah Y. Tabel 6 menunjukkan gaya geser dasar kayu solid dan glulam untuk kedua jenis kayu Bangkirai dan Nyatoh.

Pada Tabel 7 berikut menunjukkan nilai simpangan antar lantai dari keempat kasus untuk arah UX dan arah UY. Berdasarkan Tabel 7 di bawah diketahui bahwa nilai simpangan antar lantai memenuhi persyaratan yaitu simpangan antar lantai tidak lebih besar dari simpangan yang diizinkan sebesar 80 mm untuk semua kasus pemodelan struktur.

Tabel 7. Simpangan Antar Lantai Kayu Solid dan Glulam

\begin{tabular}{|c|c|c|c|c|c|c|c|}
\hline \multirow{2}{*}{ Tipe } & \multicolumn{4}{|c|}{$\begin{array}{l}\text { Simpangan Antai Tingkat } \\
\text { Maks }[\mathrm{mm}]\end{array}$} & \multirow{2}{*}{$\begin{array}{c}\text { Simpangan } \\
\text { Izin } \\
{[\mathrm{mm}]}\end{array}$} & \multicolumn{2}{|c|}{ Keterangan } \\
\hline & Arah $X$ & Lokasi & Arah $Y$ & Lokasi & & Arah $X$ & Arah $Y$ \\
\hline Solid Bangkirai & 12,52 & Lantai 1 & 24,50 & Lantai 1 & 80 & OK & $\mathrm{OK}$ \\
\hline Glulam Bangkirai & 12,47 & Lantai 1 & 24,39 & Lantai 1 & 80 & OK & OK \\
\hline Solid Nyatoh & 29,56 & Lantai 1 & 52,84 & Lantai 1 & 80 & OK & OK \\
\hline Glulam Nyatoh & 29,23 & Lantai 1 & 52,40 & Lantai 1 & 80 & OK & OK \\
\hline
\end{tabular}

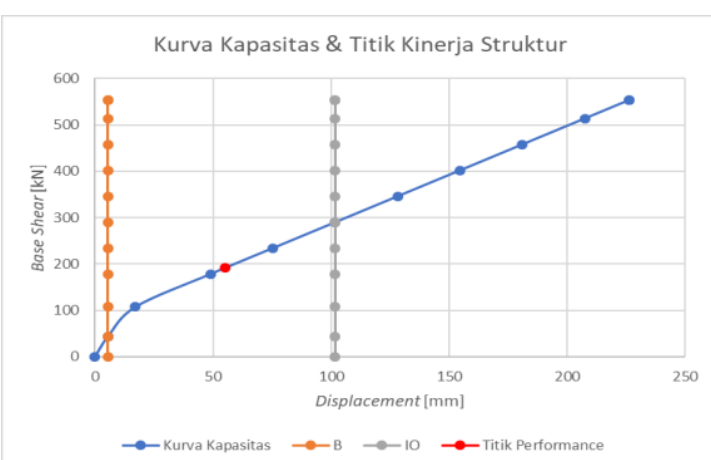

Gambar 5. Kurva Kapasitas dan Kinerja Struktur Kayu Solid Bangkirai Arah UX

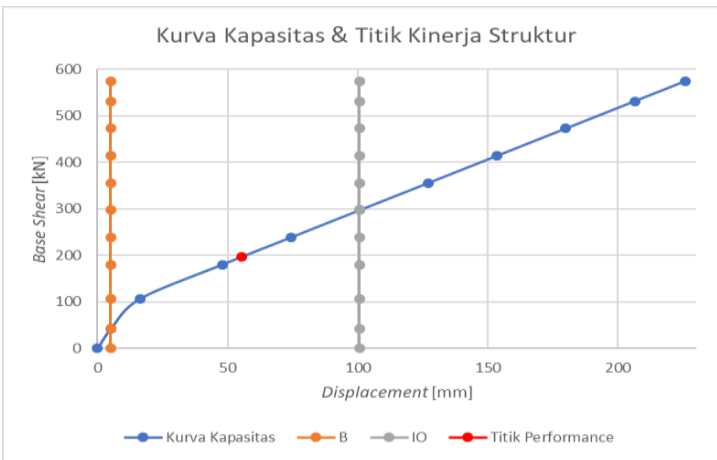

Gambar 7. Kurva Kapasitas dan Kinerja Struktur Kayu Glulam Bangkirai Arah UX

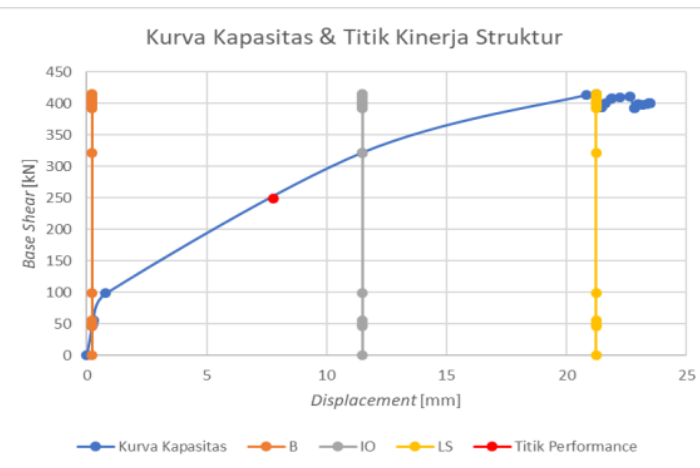

Gambar 6. Kurva Kapasitas dan Kinerja Struktur Kayu Solid Bangkirai Arah UY

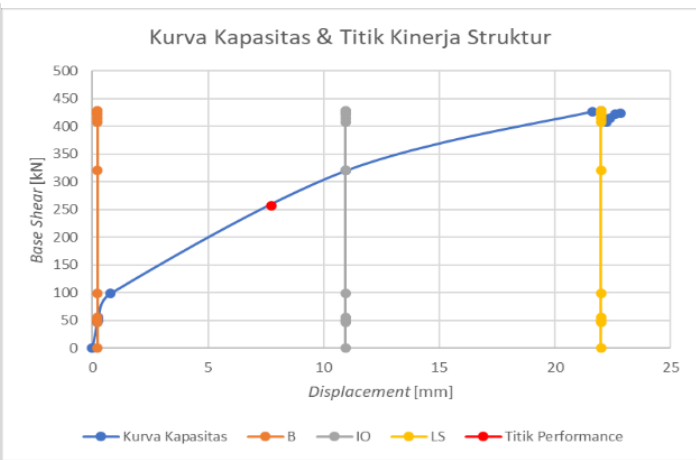

Gambar 8. Kurva Kapasitas dan Kinerja Struktur Kayu Glulam Bangkirai Arah UY 


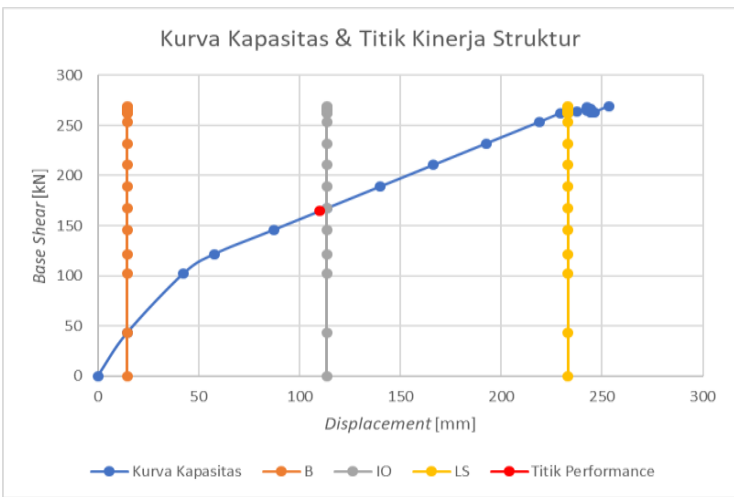

Gambar 9. Kurva Kapasitas dan Kinerja Struktur Kayu Solid Nyatoh Arah UX

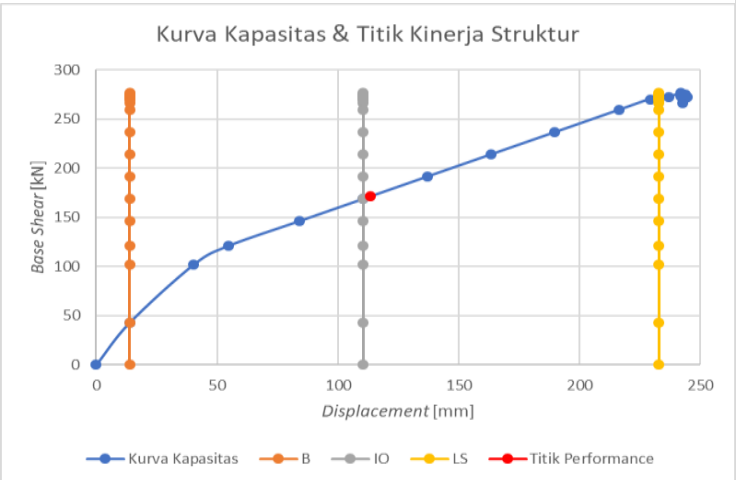

Gambar 11. Kurva Kapasitas dan Kinerja Struktur Kayu Glulam Nyatoh Arah UX

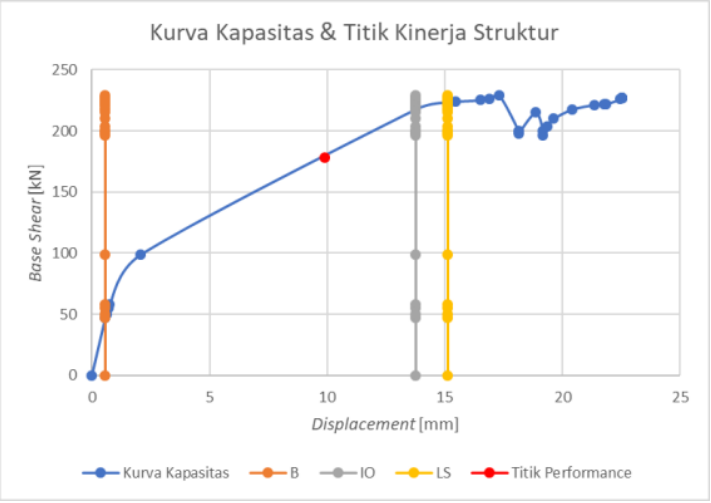

Gambar 10. Kurva Kapasitas dan Kinerja
Struktur Kayu Solid Nyatoh Arah UY

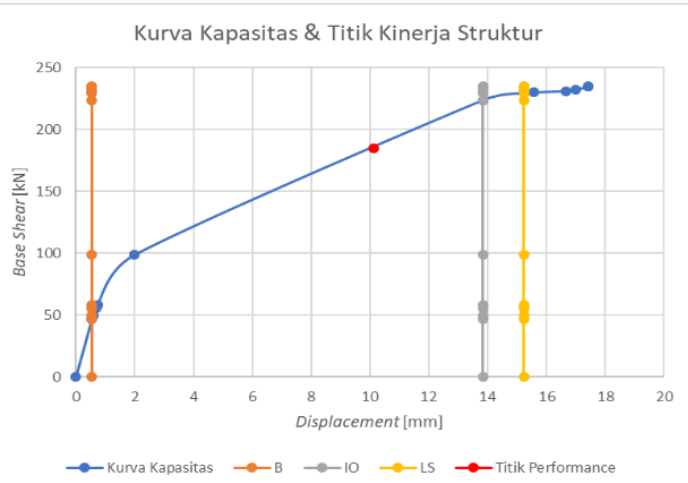

Gambar 12. Kurva Kapasitas dan Kinerja Struktur Kayu Glulam Nyatoh Arah UY

Dari Gambar 5, Gambar 6, Gambar 7, Gambar 8, Gambar 9, Gambar 10, Gambar 11, dan Gambar 12 di atas didapatkan bahwa kinerja struktur pada saat kondisi Performance Point, semua tipe struktur berada pada level yang sama yaitu berada pada kinerja B (Operationa) to IO (Immediate Occupancy) yaitu kondisi dimana ketika terjadi gempa bangunan tidak ada kerusakan yang berarti pada komponen struktural. Kekuatan dan kekakuan gedung hampir sama dengan kondisi sebelum dilanda gempa. Pada komponen non-struktural, peralatan, dan isi gedung umumnya masih aman, tetapi secara operasional tidak dapat bekerja karena kegagalan mekanik atau kurangnya utilitas.

\section{KESIMPULAN}

Berdasarkan perhitungan dan analisis struktur rumah tinggal untuk kayu glulam dan kayu solid yang menggunakan material dasar, baik kayu Bangkirai (kelas I) maupun kayu Nyatoh (kelas III), didapatkan kesimpulan sebagai berikut:

1. Berdasarkan analisis yang telah dilakukan, diperoleh periode getar alami struktur antara keempat model menunjukkan hasil yang berbeda, kayu solid Bangkirai arah $\mathrm{X}$ sebesar 0,263 detik dan arah Y sebesar 0,319 detik, kayu glulam Bangkirai arah $X$ sebesar 0,26 detik dan arah $Y$ sebesar 0,316 detik, sedangkan kayu solid Nyatoh arah $\mathrm{X}$ sebesar 0,415 detik dan arah $Y$ sebesar 0,501 detik, kayu glulam Nyatoh arah $X$ sebesar 0,409 detik dan arah $\mathrm{Y}$ sebesar 0,494 detik. Hasil tersebut dikarenakan perbedaan berat jenis sebesar 1,10 dan Modulus of Elastisity 1,05, dimana hasil tersebut didapat dari hasil konversi rumus berdasarkan BS EN 1194:1999.

2. Berdasarkan perhitungan yang dilakukan diperoleh bahwa hasil analisis gaya geser didapatkan hasil kayu solid Bangkirai arah X sebesar 23,0136 kN dan arah Y sebesar 
23,403 kN, kayu glulam Bangkirai arah $\mathrm{X}$ sebesar 23,5709 kN dan arah $\mathrm{Y}$ sebesar $24,0111 \mathrm{kN}$, sedangkan kayu solid Nyatoh arah $\mathrm{X}$ sebesar 21,4668 kN dan arah $\mathrm{Y}$ sebesar 21,7298 kN, kayu glulam Nyatoh arah X sebesar 21,8783 kN dan arah $Y$ sebesar $22,1721 \mathrm{kN}$. Hasil tersebut dikarenakan perbedaan berat jenis sebesar 1,10 dan Modulus of Elastisity 1,05, dimana hasil tersebut didapat dari hasil konversi rumus berdasarkan BS EN 1194:1999.

3. Berdasarkan perhitungan yang telah dilakukan diperoleh bahwa nilai simpangan antar lantai untuk kayu kenis Bangkirai lebih kecil daripada simpangan antar lantai untuk jenis kayu Nyatoh, dengan hasil rata-rata simpangan 3,606 mm untuk arah $\mathrm{X}$ dan arah $\mathrm{Y}$ sebesar 6,616 mm untuk kayu solid, sedangkan untuk kayu glulam arah $X$ sebesar 3,515 $\mathrm{mm}$ dan arah $\mathrm{Y}$ sebesar 6,6005 mm.

4. Berdasarkan analisis non-linier pushover didapatkan bahwa semua tipe struktur berada pada level yang sama yaitu berada pada kinerja B (Operational) to IO (Immediate Occupancy) yaitu kondisi dimana ketika terjadi gempa, bangunan tidak ada kerusakan yang berarti pada komponen struktural. Kekuatan dan kekakuan gedung hampir sama dengan kondisi sebelum dilanda gempa. Pada komponen non-struktural, peralatan, dan isi gedung umumnya masih aman, tetapi secara operasional tidak dapat bekerja karena kegagalan mekanik atau kurangnya utilitas.

\section{SARAN}

Setelah melakukan penelitian ini, penulis memberikan saran yang mungkin bermanfaat bagi pengembangan penelitian ini ditahap selanjutnya.

1. Perlu dilakukan penelitian dan analisis untuk berbagai macam jenis kayu solidlainnya yang lebih baik kekuatannya sebagai sumber acuan dalam mendesain struktur rumah tinggal 2 lantai.

2. Perlu dilakukan pembahasan dan perhitungan lebih lanjut mengenai perekat pada kayu glulam yang mempengaruhi kekuatan material itu sendiri dalam mendesain struktur rumah tinggal 2 lantai.

\section{DAFTAR RUJUKAN}

Badan Standardisasi Nasional. (2012). SNI 1726:2012 tentang Tata Cara Perencanaan Ketahanan Gempa untuk Struktur Bangunan Gedung dan Non Gedung. Jakarta: Badan Standardisasi Nasional.

Badan Standardisasi Nasional. (2013). SNI 1727:2013 tentang Beban Minimum untuk Perancangan Bangunan Gedung dan Struktur Lain. Jakarta: Badan Standardisasi Nasional.

BS EN 1194:1999. (1999). Timber Structures. Glued laminated timber. Strength classes and determination of characteristic values.UK: BSI.

Sulastiningsih, I.M. (2005). Pengaruh lapisan kayu terhadap sifat bambu lamina. Jurnal Penelitian Hasil Hutan, 23(3), 246-251. 